\title{
Faktor yang Memengaruhi Akuntabilitas Pengelolaan Dana Desa Di Kecamatan Denpasar Utara
}

\author{
Kadek Danu Dwika Riyatna1 \\ Fakultas Ekonomi dan Bisnis \\ Universitas Udayana, Indonesia
}

\author{
Gayatri ${ }^{2}$ \\ Fakultas Ekonomi dan Bisnis \\ Universitas Udayana, Indonesia
}

\begin{abstract}
Surel: danudwika96@gmail.com
ABSTRAK

Akuntabilitas merupakan tanggung jawab pemerintah desa terkait pengelolaan dana desa kepada masyarakat secara transparan, jujur, tertib dan disiplin. Tujuan diberikannya dana desa selaras dengan UU No. 6 Tahun 2014 yaitu untuk meningkatkan kesejahteraan masyarakat. Penelitian ini bertujuan untuk mengetahui pengaruh kepemimpinan kepala desa, kompetensi perangkat desa dan partisipasi masyarakat terhadap akuntabilitas pengelolaan dana pada 8 desa di Kecamatan Denpasar Utara dengan 178 responden. Pengumpulan data dengan menggunakan kuesioner. Teknik analisis data yang digunakan yaitu analisis regresi linear berganda. Hasil penelitian menunjukkan bahwa kepemimpinan kepala desa dan kompetensi perangkat desa yang memiliki pengaruh positif terhadap akuntabilitas pengelolaan dana desa di Kecamatan Denpasar Utara, sedangkan partisipasi masyarakat tidak berpengaruh signifikan terhadap akuntabilitas pengelolaan dana desa di Kecamatan Denpasar Utara.
\end{abstract}

Kata Kunci: Akuntabilitas; Kepemimpinan; Kompetensi; Dan Partisipasi Masyarakat.

\section{Factors Affecting Accountability of Village Fund Management in North Denpasar District}

ABSTRACT

Accountability is the responsibility of the village government regarding the management of village funds to the community in a transparent, honest, orderly and disciplined manner. The purpose of providing village funds is in line with Lawno. 6 of 2014 which is to improve the welfareof the community. This study aims to determine the effect of village head leadership, village apparatus competence and community participation on fund management accountability in 8 villages in North Denpasar District with 178 respondents. Data collection by using a questionnaire. The data analysis technique used is multiple linear regression analysis. The results showed that the leadership of the village head and the competence of the village apparatus had a positive influence on the accountability of village fund management in North Denpasar District, while community participation had no significant effect on the accountability of village fund management in North Denpasar District.

Keywords: Accountability; Leadership; Competence; And Community Participation.

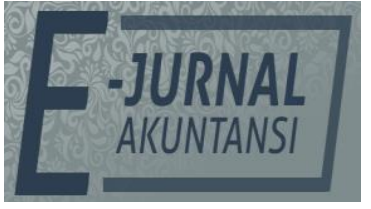

e-ISSN 2302-8556

Vol. 31 No. 12

Denpasar, Desember 2021

Hal. 3273-3287

DOI:

10.24843/EJA.2021.v31.i12.p18

PENGUTIPAN:

Riyatna, K. D. D. \& Gayatri, G. (2021). Faktor yang

Memengaruhi Akuntabilitas

Pengelolaan Dana Desa Di

Kecamatan Denpasar Utara.

E-Jurnal Akuntansi, 31(12), 3273-3287

RIWAYAT ARTIKEL:

Artikel Masuk: 13 Juli 2021

Artikel Diterima: 15 November 2021

Artikel dapat diakses: https:/ / ojs.unud.ac.id/index.php/Akuntansi/index 


\section{PENDAHULUAN}

Membangun Indonesia dari pinggiran dengan memperkuat daerah-daerah dan desa merupakan agenda prioritas nasional dalam pemerintahan Presiden Jokowi. Pembangunan pedesaan ditujukan untuk meningkatkan kesejahteraan dan kualitas hidup masyarakat desa. UU No. 6 Tahun 2014 mewajibkan pemerintah mengalokasikan dana desa melalui Anggaran Pendapatan dan Belanja Negara (APBN) sebagai sumber pendapatan desa. Pendapatan desa yang terdiri atas pendapatan asli desa, dana desa yang bersumber dari APBN, bagian dari hasil Pendapatan Daerah dan Retribusi Daerah (PDRD) Kabupaten/kota, alokasi dana desa dari Kabupaten/kota, bantuan keuangan dari APBD Provinsi dan APBD Kabupaten/ kota, serta hibah dan sumbangan pihak ketiga. Dana Desa Merupakan dana APBN yang diperuntukkan bagi desa yang di transfer melalui APBD kabupaten/ kota. Penganggaran dana desa dalam APBN ditentukan $10 \%$ dari dana transfer daerah secara bertahap dengan memperhatikan jumlah penduduk, angka kemiskinan, luas wilayah serta tingkat kesulitan geografis suatu daerah. Pada tahun 2020 Provinsi Bali memperoleh dana desa sebesar Rp 657.798.211, mengalami peningkatan dari tahun sebelumnya yang memperoleh dana desa sebesar Rp 630.189.586.

Permasalahan dalam pengelolaan keuangan desa disebabkan oleh minimnya pengetahuan perangkat desa dalam pengelolaan dan pelaporan keuangan desa, sehingga akan berpotensi terjadinya penyalahgunaan kekuasan berupa tindakan korupsi (Yusof, 2016). Akuntabilitas merupakan suatu alat untuk memastikan kepercayaan masyarakat terhadap perangkat pemerintah serta menjembatani kesenjangan antara masyarakat dengan pemerintah (Mahayani, 2017). Akuntabilitas pengelolaan dana desa merupakan bagian dari akuntansi sektor publik, mengingat dana yang diperoleh dalam pengelolaan dana desa bersumber dari dana publik dan digunakan untuk pelayanan publik. Menurut teori agensi tentang pengelolaan dana desa, pemerintah pusat dan masyarakat merupakan pemilik (principal) dan pemerintah daerah sebagai agen yang diberikan kepercayaan dalam mengelola dana yang ada. Sehingga perlu adanya tanggung jawab dalam pengelolaan dana desa (Vesey, 2019). Pertanggungjawaban yang dimaksud tidak hanya mencakup pertanggungjawaban keuangan secara formal dalam organisasi, tetapi juga mencakup kepatuhan pada aturan, lingkungan organisasi, masyarakat dan pemerintah (Mahayani, 2017). Untuk mencapai akuntabilitas pemerintah selaku pengelola dana publik harus memperhatikan anggaran, pengendalian akuntansi, dan sistem pelaporan keuangan (Rahman et al., 2016). Beberapa hambatan dalam pengelolaan dana desa diantaranya adalah kurangnya kapasitas sumber daya perangkat desa dan kurangnya tingkat partisipasi masyarakat. Selain itu keberhasilan pembangunan desa dapat dilihat dari beberapa faktor, yakni kapasitas perangkat desa, partisipasi masyarakat, dan kepemimpinan kepala desa (Han \& Perry, 2020).

Kepemimpinan yang mumpuni dari seorang individu diperoleh dari proses pendidikan dan juga pengalaman. Semakin baik tokoh pemerintah mengetahui kepentingan masyarakat dan memiliki hubungan kerja sama yang baik dengan masyarakat, maka masyarakat akan semakin baik dalam melaksanakan dan membantu pemerintah dalam pengelolaan perangkat daerah (Dewi \& Gayatri, 2019). Dalam ajaran agama Hindu kepemimpinan yang baik 
hendaknya dapat menerapkan konsep kepemimpinan Asta Brata, yang dimana secara garis besar kepemimpinan adalah untuk dapat mencapai kesejahteraan masyarakat. Semakin baik hubungan kerjasama antara pemimpin dan masyarakatnya, maka semakin meningkat pula kesejahteraan masyarakat dalam membantu perangkat desa/ pemimpin dalam mensukseskan pembangunan yang telah dilaksanakan oleh pemerintah. Kepemimpinan dalam pengelolaan dana desa mengacu pada kepemimpinan kepala desa. Seorang kepala desa selaku pemegang pengelolaan keuangan desa berperan sangat penting guna mencapai kesejahteraan masyarakat. Penelitian oleh Pawirosumar to et al. (2017) menyatakan bahwa gaya kepemimpinan berpengaruh positif terhadap kinerja pegawai. Penelitian tersebut bertentangan dengan hasil penelitian oleh Mahayani yaitu tidak terdapat pengaruh kepemimpinan terhadap akuntabilitas pengelolaan dana desa (Mahayani, 2017).

Kompetensi dan pemahaman dari aparatur desa mempengaruhi kepemimpinan yang mumpuni dalam pengelolaan anggaran dana desa. Minimnya kompetensi suatu perangkat desa akan sangat mempengaruhi bahkan menjadi faktor penghambat dalam proses pengelolaan suatu dana desa. Sedangkan tingginya kompetensi sumber daya manusia dalam suatu perangkat desa menentukan kualitas dari perangkat desa tersebut. Dalam hal tersebut menunjukkan bahwa semakin baik kompetensi yang dimiliki oleh suatu perangkat desa akan dikatakan akuntabel sedangkan rendahnya kompetensi yang dimiliki oleh suatu perangkat desa merupakan salah satu penyebab terjadinya pelanggaran atau korupsi yang tidak sengaja dalam pengelolaan dana desa yang dilakukan oleh perangkat desa.

Beberapa faktor yang menjadi penghambat pengelolaan dana desa diantaranya terbatasnya kemampuan aparatur pemerintah desa dalam pelaksanaan alokasi dana desa. "Berdasarkan hasil penelitian dari Pramayoga \& Ramantha (2019) kompetensi aparatur desa berpengaruh signifikan terhadap akuntabilitas keuangan daerah. Penelitian tersebut sejalan dengan hasil penelitian dari Mantako et al. (2019) yang menyimpulkan bahwa kompetensi berpengaruh positif pada akuntabilitas. Namun hasil penelitian tersebut bertentangan dengan hasil yang dilakukan oleh Prasetya dan kawan-kawan yang menyimpulkan bahwa kompetensi sumber daya berpengaruh negatif terhadap kualitas penerapan SISKEUDES (Prasetya et al., 2017).

Partisipasi masyarakat dapat diartikan sebagai keterlibatan masyarakat sebagai individu atau kelompok sosial yang berperan dalam pembangunan desa dari proses perencanaan hingga implementasi (Arta \& Rasmini, 2019). Dalam pengelolaan keuangan desa, partisipasi masyarakat dapat meningkatkan pembangunan desa. Masyarakat desa dan lembaga kemasyarakatan desa memiliki peran dalam melakukan pengawasan terhadap kinerja perangkat desa dalam pengelolaan dana desa untuk menghindari penyalahgunaan kekuasaan Pengelolaan dana desa yang ideal harus dilakukan dengan melibatkan peran sertanya partisipasi masyarakat desa, hal tersebut disebabkan karena masyarakat desa terkait yang mengetahui dan mengerti permasalahan maupun potensi yang ada di desa (Mahayani, 2017). Berdasarkan hasil penelitian dari Dewi dan Gayatri menyimpulkan bahwa partisipasi berpengaruh positif pada akuntabilitas pengelolaan dana desa (Dewi \& Gayatri, 2019). Hasil penelitian tersebut sejalan 
dengan hasil penelitian Arta dan Rasmini yang menyimpulkan bahwa partisipasi masyarakat berpengaruh positif pada akuntabilitas pengelolaan dana desa (Arta \& Rasmini, 2019). Namun hasil penelitian tersebut bertentangan dengan hasil penelitian yang dilakukan oleh Retnaningtyas bahwa partisipasi tidak berpengaruh terhadap akuntabilitas kinerja keuangan (Retnaningtyas, 2016).

Kota Denpasar sebagai daerah yang memperoleh dana desa terendah di Provinsi Bali ditambah adanya kasus penyalahgunaan kekuasaan yang dilakukan oleh perangkat desa di Kota Denpasar. Fenomena tersebut diperkuat dengan adanya perbedaan hasil penelitian yang inkonsisten oleh peneliti sebelumnya mengenai akuntabilitas. Berdasarkan pemaparan tersebut, kerangka konseptual menyajikan hubungan antar variabel dapat dilihat pada Gambar 1.

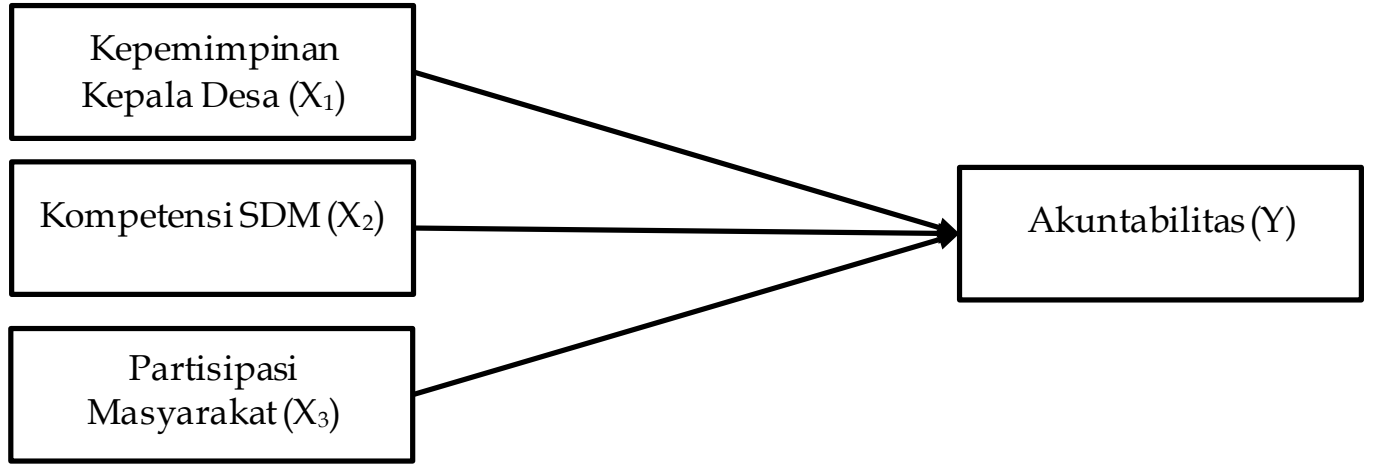

Gambar 1. Kerangka Konseptual

Sumber: Data Penelitian, 2021

Teori peran menegaskan bahwa kepala desa dalam tugasnya mengelola dana desa berperan sebagai penanggung jawab dalam bentuk anggaran. Kepala desa (Perbekel) bertanggung jawab dengan memberi laporan realisasi pelaksanaan APBDesa ke pemerintah. Undang - Undang No. 6 Tahun 2014 Pasal 29 tentang desa menjelaskan bahwa kepala desa dilarang merugikan kepentingan masyarakat umum, membuat keputusan yang menguntungkan individu, menyalahgunakan wewenang, tugas, hak, dan/atau kewajibannya, melakukan kolusi, korupsi, nepotisme dan sebagainya (Curral et al., 2016). Tercapainya suatu tujuan dari organisasi sangat dipengaruhi oleh peran pemimpin (Dewi \& Gayatri, 2019). Upaya yang dapat dilakukan untuk memengaruhi bawahannya untuk bekerja lebih baik adalah dengan cara menjalin hubungan yang baik dengan bersikap ramah dengan bawahannya. Hal seperti inilah yang diharapkan setiap bawahan yaitu pemimpin tidak memperlakukannya hanya sebagai sarana produksi. Pemimpin yang dapat memberi pengaruh kepada bawahan untuk melaksanakan tugas dan kewajiban dengan lebih baik dalam mencapai tujuan merupakan gaya kepemimpinan yang baik (Ratu et al., 2018).

Penelitian terdahulu tentang kepemimpinan yang dilakukan oleh Pertiwi (2017) menyimpulkan bahwa gaya kepemimpinan secara parsial berpengaruh positif terhadap kinerja pemerintah daerah. Pramayoga \& Ramantha (2019) menyimpulkan bahwa kepemimpinan berpengaruh positif pada akuntabilitas pengelolaan dana desa. Dapat disimpulkan bahwa kepemimpinan kepala desa (perbekel) berkaitan dengan peran yang diperoleh, sehingga dengan peran tersebut muncul tanggung jaw ab untuk melaksanakan tugas sesuai dengan aturan 
dan norma berlaku. Berdasarkan uraian tersebut, hipotesis yang diajukan dalam penelitian ini adalah.

$\mathrm{H}_{1}$ : Kepemimpinan Kepala Desa berpengaruh positif pada akuntabilitas pengelolaan dana desa.

Kepatuhan seseorang pada aturan dan norma yang berlaku menjadi cerminan atas kompetensi yang dimilikinya. Kompetensi perangkat desa sangat diperlukan dalam pengelolaan dana desa dalam pembangunan berbagai aspek dengan memiliki pengalaman, pengetahuan, kecerdasan, keterampilan dan perilaku untuk meningkatkan pembangunan yang optimal (Anto \& Amir, 2017). Dalam mengelola dana desa, perangkat desa harus taat dan mematuhi aturan yang telah ditetapkan dalam Undang - Undang yang menuntut adanya akuntabilitas (Dewi \& Gayatri, 2019). Kompetensi dapat diartikan sebagai karakteristik individu yang berkaitan dengan keunggulan seseorang dalam melakukan tugas dan kewajiban. Tuntutan akan akuntabilitas dalam mengelola dana desa harus disertai dengan mempekerjakan individu yang memiliki kompetensi di bidang yang ditekuni (Prasetya et al., 2017). Dewi \& Gayatri (2019) menyimpulkan bahwa kompetensi berpengaruh positif terhadap akuntabilitas.

$\mathrm{H}_{2}$ : Kompetensi perangkat desa berpengaruh positif pada akuntabilitas pengelolaan dana desa.

Dalam teori keagenan, partisipasi masyarakat merupakan salah satu cara meminimalisir terjadinya konflik antar prinsipal dan agen (Atmadja \& Saputra, 2018). Masyarakat sebagai prinsipal berhak untuk memperoleh pertanggungjawaban dari agen atas yang dilakukan (Dewi \& Gayatri, 2019). Dengan terlibatnya masyarakat akan mengoptimalkan pembangunan desa karena masyarakat sendirilah yang mengetahui kondisi dan potensi maupun masalah yang ada (Mahayani, 2017). Masyarakat tidak hanya berperan aktif dalam perencanaan dan pengawasan, melainkan juga dalam pelaksanaannya, serta penerimaan dan pemanfaatan dari hasilnya (Sugista, 2017). "Berdasarkan hasil penelitian yang dilakukan Arta \& Rasmini (2019) menyimpulkan bahwa partisipasi masyarakat berpengaruh positif pada akuntabilitas pengelolaan dana desa. Hasil penelitian serupa juga diperoleh oleh Dewi \& Gayatri (2019). Serta penelitian yang dilakukan oleh Sugista (2017) menyimpulkan bahwa partisipasi masyarakat dalam mengelola keuangan dana desa akan meningkatkan pembangunan desa. Dapat disimpulkan bahwa peran partisipasi masyarakat dalam pembangunan sangat penting, karena masyarakatlah yang paling mengetahui kondisi dan permasalahan yang terjadi. Aparat perangkat daerah memang sudah seharusnya menyadari tugas dan tanggungjawab sebagai pihak yang mengelola dan harus mematuhi aturan yang berlaku (Carreira et al., 2017)."

$\mathrm{H}_{3}$ : Partisipasi masyarakat berpengaruh positif pada akuntabilitas pengelolaan dana desa.

\section{METODE PENELITIAN}

Penelitian ini dilakukan dengan menggunakan pendekatan kuantitatif yang berbentuk penelitian asosiatif, yaitu penelitian yang bertujuan untuk mengetahui pengaruh maupun hubungan antara dua variabel atau lebih. Penelitian ini dilakukan di Kota Denpasar, Kecamatan Denpasar Utara dengan mengambil sampel 8 desa yang ada di Denpasar Utara. Obyek dalam penelitian ini adalah 
pengaruh kepemimpinan kepala desa, kompetensi dan partisipasi masyarakat pada akuntabilitas pengelolaan dana desa di Kecamatan Denpasar Utara."

Populasi dalam penelitian ini yaitu perangkat desa yang terdiri dari kepala desa (perbekel), sekretaris desa, serta kaur keuangan. Kelembagaan desa yang terdiri dari Kelian Adat, Badan Permusyawaratan Desa (BPD) dan Lembaga Pemberdayaan Masyarakat (LPM). Kelembagaan dalam masyarakat terdiri dari Pemberdayaan Kesejahteraan Keluarga (PKK), Ketua Sekaa Truna Truni (STT) yang ada di Kecamatan Denpasar Utara, Kota Denpasar. Jadi, total responden dari 8 desa yang ada di Kecamatan Denpasar Utara adalah 178 responden. Teknik purposive sampling digunakan untuk menentukan responden berdasarkan kriteria tertentu yang sesuai dengan fenomena yang diteliti. Metodepengumpulan data yang digunakan dalam penelitian ini adalah metode survei dengan teknik kuesioner yang diisi oleh kepala desa, sekretaris desa, kaur keuangan, LPM, BPD, Kelian adat, ketua PKK dan ketua STT di Kecamatan Denpasar Utara. Data dikumpulkan dari para responden dengan menggunakan kuesioner dengan skala likert 1 sampai 5, yaitu jawaban responden akan diberi nilai dengan skala 1 untuk skor terendah dan skala 5 untuk skor tertinggi. Dalam penelitian ini, analisis regresi linear berganda dilakukan guna mengetahui adanya pengaruh variabel bebas terhadap variabel terikat.

\section{HASIL DAN PEMBAHASAN}

Responden penelitian yang dilakukan sebanyak 5 orang dari perangkat desa di setiap desa yang ada di Kecamatan Denpasar Utara. Responden yang dimaksud adalah kepala desa, sekretraris desa, kaur keuangan desa, BPD desa, LPM desa, kelian adat, ketua PKK dan ketua STT. Pemilihan responden mengacu pada Permendagri No. 20 Tahun 2018. Jumlah desa yang ada di kecamatan Denpasar Utara adalah 8 desa, jumlah responden sebanyak 178 orang. Tingkat pengembalian kuesioner adalah sebesar 100 persen. Seluruh kuesioner diisi dengan baik oleh responden, sehingga seluruh kuesioner dapat digunakan.

Responden dalam penelitian ini "sebagian besar berjenis kelamin laki-laki, yaitu berjumlah 121 orang $(67,98$ persen), sedangkan responden yang berjenis kelamin perempuan berjumlah 57 orang (32,02 persen)." Artinya, masih ada kesenjangan jumlah perangkat wanita yang memiliki peran inti dalam pemerintahan. Pengangkatan wanita sebagai bagian dari perangkat desa maupun dusun mungkin saja berdasarkan pada pertimbangan peran ganda yang dimilikinya, wanita dengan peran ganda memiliki beban kerja yang lebih besar karena harus membagi fokusnya untuk mengerjakan tugas sebagai perangkat desa dan juga sebagai seorang ibu serta istri. Keberadaan peran ganda ini bisa menjadi salah satu faktor yang memengaruhi akuntabilitas pengelolaan dana desa menjadi tersendat. Keberhasilan peran laki-laki sebagai pemimpin dianggap berasal dari faktor internal yaitu kemampuan dan juga keterampilan, sedangkan perempuan dianggap berhasil karena faktor eksternal yaitu keberuntungan dan juga tugas yang lebih ringan. Kemampuan yang dimaksud adalah kemampuan dalam menghadapi masalah, dan mengambil keputusan. Kemampuan ini menjadi poin penting yang dapat digunakan dalam hal mengelola dana desa dari proses penganggaran sampai dengan pelaporan yang akhirnya mampu mencapai akuntabilitas. 
Responden yang berusia 21-35 tahun berjumlah 52 orang $(29,22$ persen), responden yang berusia 36-50 tahun berjumlah 64 orang (35,95 persen), dan responden yang berusia $>50$ tahun berjumlah 62 orang (34,83 persen). Dapat disimpulkan bahwa responden dalam penelitian ini sebagian besar berusia antara 36-50 tahun. Dapat dijelaskan bahwa responden dalam penelitian ini termasuk usia dewasa awal (18 - 40 tahun) dan dewasa madya (41 - 60 tahun). Umur dapat dijadikan patokan kematangan dan kekuatan seseorang dalam bekerja dan juga berpikir dalam mengambil keputusan. Metode koping dapat diartikan sebagai kemampuan individu dalam mengatasi stres yang berasal dari dalam dirinya atau dari luar. Stres dapat muncul karena banyaknya pekerjaan yang harus diselesaikan oleh perangkat desa. Kemampuan seseorang mengelola emosi dan stress dapat dipengaruhi oleh usia, hal ini karena tiap tahun yang dilewati akan memberikan individu pengalaman untuk mengatasi permasalahan yang dihadapi. Oleh karena itu, perangkat desa maupun dusun yang ada di seluruh desa Kecamatan Denpasar Utara dianggap mampu untuk menyelesaikan permasalahan yang dihadapi dalam proses pelaksanaan anggaran dan mewujudkan akuntabilitas pengelolaan dana desa.

Seluruh responden dalam penelitian ini berstatus menikah yang jumlahnya sebanyak 132 orang (74,16 persen). Sedangkan yang berstatus belum menikah jumlahnya sebanyak 46 orang $(25,84$ persen). Dapat dijelaskan bahwa sebagian besar responden dalam penelitian ini sudah menikah mengingat data usia sudah melewati batas usia minimal yang diatur dalam Undang-Undang. Keberadaan dukungan sosial yang berasal dari teman, pasangan, dan juga keluarga dapat mengurangi gejala kejenuhan kerja yang timbul karena adanya tuntutan kerja (Adnyaswari \& Adnyani, 2017). Semakin tinggi kejenuhan kerja yang dialami oleh individu maka akan memengaruhi kinerjanya. Dengan demikian dapat disimpulkan bahwa perangkat desa yang ada di Kecamatan Denpasar Utara memiliki tingkat kejenuhan kerja yang rendah, sehingga perangkat desa mampu untuk menjalankan tugasnya sebagai pengelola dana desa dan mampu mewujudkan akuntabilitas.

Responden dalam penelitian ini sebagian besar berlatar belakang pendidikan SMA yang jumlahnya 52 orang $(29,21$ persen), berlatar belakang Diploma jumlahnya 9 orang (5,06 persen), dan berlatar belakang Sarjana jumlahnya 117 orang (65,73 persen). Dapat dijelaskan bahwa perangkat desa di setiap desa di Kecamatan Denpasar Utara sebagian besar berlatar belakang pendidikan S1. Pendidikan memiliki peran penting dalam meningkatkan kualitas kemampuan profesional individu, melalui pendidikan individu dipersiapkan untuk memiliki daya saing serta kemampuan dalam mengembangkan metode berpikir secara sistematis untuk dapat menyelesaikan permasalahan yang dihadapi. Dengan latar belakang pendidikan yang dimiliki serta adanya kemauan dari perangkat desa untuk belajar, maka dalam melaksanakan tugasnya mengelola dana desa perangkat desa mampu mencapai tujuan yang diharapkan dari adanya pemberian dana desa.

Responden dengan lama bekerja 1-5 tahun berjumlah 157 orang $(88,2$ persen), responden dengan lama bekerja 6-10 tahun berjumlah 8 orang $(4,5$ persen), responden dengan lama bekerja 11-15 tahun berjumlah 3 orang $(1,69$ persen), dan responden dengan lama bekerja $>15$ tahun berjumlah 10 orang $(5,61$ 
persen). Sehingga responden dalam penelitian ini sebagian besar baru bekerja antara 1-5 tahun. Lama bekerja menunjukkan seberapa mampu seseorang dalam menyelesaikan tugasnya. Kemampuan ini diperoleh dari proses belajar serta dukungan dari rekan kerja. Semakin lama seseorang bekerja dalam suatu organisasi, maka orang tersebut akan memiliki pengalaman dalam menghadapi permasalahan dan menyelesaikannya. Kinerja individu dapat ditingkatkan apabila lama bekerja disertai dengan adanya kemauan untuk belajar, sehingga apa yang diharapkan dari diberikannya dana desa dapat terwujud.

Hasil uji validitas menunjukkan "bahwa seluruh instrumen penelitian yang digunakan untuk mengukur variable kepemimpinan kepala desa, kompetensi, partisipasi masyarakat dan akuntabilitas pengelolaan dana desa memiliki nilai koefisien korelasi dengan skor total seluruh item pernyataan lebih besar dari 0.30 dengan signifikansi kurang dari 0.05 . Hal ini menunjukkan bahwa butir-butir pernyataan dalam instrumen penelitian tersebut valid dan layak digunakan sebagai instrumen penelitian. Hasil uji reliabilitasmenunjukkan bahwa seluruh instrumen penelitian memiliki koefisien Cronbach's Alpha lebih dari 0,60. Jadi, dapat dinyatakan bahwa seluruh variabel telah memenuhi syarat reliabilitas atau keandalan sehingga dapat digunakan untuk melakukan penelitian."

Tabel 1. Hasil Statistik Deskriptif Variabel Penelitian

\begin{tabular}{lccccc}
\hline & $\mathrm{N}$ & Minimum & Maximum & Mean & $\begin{array}{c}\text { Std. } \\
\text { Deviation }\end{array}$ \\
\hline Kepemimpinankepaladesa & 178 & 21,00 & 35,00 & 27,247 & 3,890 \\
Kompetensi perangkat desa & 178 & 30,00 & 50,00 & 44,320 & 4,873 \\
Partisipasi masyarakat & 178 & 17,00 & 30,00 & 26,157 & 2,879 \\
Akuntabilitas pengelolaan dana desa & 178 & 30,00 & 40,00 & 35,376 & 3,293 \\
Valid N (listwise) & 178 & & & & \\
\hline
\end{tabular}

Sumber: Data Penelitian, 2020

Variabel kepemimpinan kepala desa memiliki nilai minimum sebesar 21,00 dan nilai maksimum sebesar 35,00. Nilai rata-rata sebesar 27,247 menunjukkan bahwa keberadaan kejelasan sasaran anggaran berpengaruh terhadap akuntabilitas pengelolaan dana desa serta penyimpangan nilai rata-ratanya ditunjukkan melalui angka pada standar deviasi sebesar 3,890. Variabel kompetensi perangkat desa memiliki nilai minimum sebesar 30,00 dan nilai maksimum sebesar 50,00. Nilai rata-rata sebesar 44,320 menunjukkan bahwa keberadaan kompetensi perangkat desa berpengaruh terhadap akuntabilitas pengelolaan dana desa serta penyimpangan nilai rata-ratanya ditunjukkan melalui angka pada standar deviasi sebesar 4.873. Variabel partisipasi masyarakat memiliki nilai minimum sebesar 17,00 dan nilai maksimum sebesar 30,00. Nilai rata-rata sebesar 26.157 menunjukkan bahwa keberadaan kepemimpinan kepala desa berpengaruh terhadap akuntabilitas pengelolaan dana desa serta penyimpangan nilai rata-ratanya ditunjukkan melalui angka pada standar deviasi sebesar 2,879. Variabel akuntabilitas memiliki nilai minimum sebesar 30,00 dan nilai maksimum sebesar 40,00. Nilai rata-rata sebesar 35,376 dengan penyimpangan nilai rata-ratanya ditunjukkan melalui angka pada standar deviasi sebesar 3,293. 
Tabel 2. Hasil Uji Normalitas

\begin{tabular}{ll}
\hline & Unstandardized Residual \\
\hline $\mathrm{N}$ & 178 \\
Kolmogorov-Smirnov $\mathrm{Z}$ & 0,244 \\
Asymp.Sig.(2-tailed) & 0,244 \\
\hline
\end{tabular}

Sumber: Data Penelitian, 2020

Berdasarkan hasil analisis didapat nilai signifikansi sebesar 0,244, karena nilai signifikansi uji Kolmogorov-Smirnov lebih dari 0,05 maka dapat disimpulkan bahwa model persamaan regresi tersebut berdistribusi normal.

Tabel 3. Hasil Uji Multikoleniaritas

\begin{tabular}{lll}
\hline Variabel & Tolerance & VIF \\
\hline Kepemimpinan kepala desa $\left(\mathrm{X}_{1}\right)$ & 0,944 & 1,060 \\
Kompetensi perangkat desa $\left(\mathrm{X}_{2}\right)$ & 0,486 & 2,058 \\
Partisipasi masyarakat $\left(\mathrm{X}_{3}\right)$ & 0,472 & 2,117 \\
\hline
\end{tabular}

Sumber: Data Penelitian, 2020

Berdasarkan Tabel 3, dapat dilihat bahwa nilai tolerance dan VIF dari seluruh variabel tersebut menunjukkan bahwa nilai tolerance untuk setiap variabel lebih besar dari 10 persen dan nilai VIF lebih kecil dari 10 yang berarti model persamaan regresi bebas dari multikolinearitas.

Tabel 4. Hasil Uji Heteroskedastisitas

\begin{tabular}{ll}
\hline Variabel & Signifikansi \\
\hline Kepemimpinankepaladesa $\left(\mathrm{X}_{1}\right)$ & 0,162 \\
Kompetensi perangkat desa $\left(\mathrm{X}_{2}\right)$ & 0,279 \\
Partisipasi masyarakat $\left(\mathrm{X}_{3}\right)$ & 0,088 \\
\hline
\end{tabular}

Sumber: Data Penelitian 2020

Pada Tabel 4, dapat dilihat bahwa nilai Signifikansi dari variabel kejelasan sasaran anggaran, kompetensi perangkat desa, kepemimpinan kepala desa, partisipasi masyarakat, dan sistem pelaporan masing-masing memiliki nilai yang lebih besar dari 0,05 yang berarti tidak terdapat pengaruh antara variabel bebas terhadap absolute residual. Dengan demikian, model yang dibuat tidak mengandung gejala heteroskedastisitas.

Berdasarkan Tabel 5, nilai konstanta 7,613 menunjukkan apabila variabel kepemimpinan kepala desa $\left(X_{1}\right)$, kompetensi perangkat desa $\left(X_{2}\right)$, dan partisipasi masyarakat $\left(X_{3}\right)$ bernilai atau sama dengan 0 (konstan), maka variabel akuntabilitas pengelolaan dana desa (Y) meningkat sebesar 7,613. Variabel kepemimpinan kepala desa $\left(\mathrm{X}_{1}\right)$ memiliki nilai koefisien sebesar 0,077 yang menunjukkan bahwa terdapat pengaruh positif pada variabel akuntabilitas $(\mathrm{Y})$ yang artinya bahwa apabila variabel kejelasan sasaran anggaran $\left(\mathrm{X}_{1}\right)$ naik sebesar satu satuan dengan asumsi variabel lain dianggap konstan, maka variabel akuntabilitas meningkat sebesar 0,077 . Variabel kompetensi perangkat desa $\left(\mathrm{X}_{2}\right)$ memiliki nilai koefisien sebesar 0,121 yang menunjukkan bahwa terdapat pengaruh positif pada variabel akuntabilitas ( $\mathrm{Y}$ ) yang artinya bahwa apabila variabel kompetensi perangkat desa $\left(X_{2}\right)$ naik sebesar satu satuan dengan asumsi variabel lain dianggap konstan, maka variabel akuntabilitas meningkat sebesar 0,121 . Variabel Partisipasi masyarakat $\left(X_{3}\right)$ memiliki nilai koefisien sebesar 0,437 yang menunjukkan bahwa terdapat pengaruh positif pada variabel akuntabilitas (Y) yang artinya bahwa apabila variabel kepemimpinan kepala desa $\left(\mathrm{X}_{3}\right)$ naik 
RIYATNA, K. D. D. \& GAYATRI, G.

sebesar satu satuan dengan asumsi variabel lain dianggap konstan, maka variabel akuntabilitas meningkat sebesar 0, 437 .

Tabel 5. Hasil Analisis Regresi Linier Berganda

\begin{tabular}{|c|c|c|c|c|c|}
\hline \multirow[t]{2}{*}{ Model } & \multicolumn{2}{|c|}{$\begin{array}{l}\text { Unstandardized } \\
\text { Coefficients }\end{array}$} & \multirow[t]{2}{*}{$\begin{array}{l}\text { Standardized } \\
\text { Coefficients }\end{array}$} & \multirow[t]{2}{*}{$\mathrm{T}$} & \multirow[t]{2}{*}{ Sig. } \\
\hline & $\mathrm{B}$ & Std. Error & & & \\
\hline (Constant) & 7,613 & 2,130 & & 3,574 & 0,000 \\
\hline $\begin{array}{l}\text { Kepemimpinan } \\
\text { desa }\end{array}$ & 0,077 & 0,041 & 0,091 & 1,873 & 0,043 \\
\hline $\begin{array}{l}\text { Kompetensi perangkat } \\
\text { desa }\end{array}$ & 0,121 & 0,046 & 0,475 & 6,985 & 0,020 \\
\hline Partisipasi masyarakat & 0,437 & 0,079 & 0,382 & 5,536 & 0,180 \\
\hline R Square & & 0,609 & & & \\
\hline Adjusted R Square & & 0,602 & & & \\
\hline F hitung & & 90,253 & & & \\
\hline SignifikansiF & & 0,000 & & & \\
\hline
\end{tabular}

Sumber: Data Penelitian, 2020

Besarnya pengaruh variabel bebas terhadap variabel terikat yang ditunjukkan oleh nilai determinasi total (R Square) sebesar 0,609 mempunyai arti bahwa sebesar 60,9 persen variasi akuntabilitas pengelolaan dana desa dipengaruhi oleh variasi kepemimpinan kepala desa, kompetensi perangkat desa dan partisipasi masyarakat sedangkan sisanya sebesar 39,1 persen "dijelaskan oleh faktor lain yang tidak dimasukkan ke dalam model. Nilai $F_{\text {hitung }}$ sebesar 90,253 dengan signifikansi sebesar 0,000 < 0,05, maka dapat disimpulkan bahwa pada kelompok yang diuji memiliki perbedaan yang nyata (signifikan). Hasil ini mempunyai arti bahwa ada pengaruh signifikan antara kepemimpinan kepala desa, kompetensi perangkat desa dan partisipasi masyarakat secara simultan terhadap akuntabilitas pengelolaan dana desa.

Berdasarkan hasil analisis pengaruh kepemimpinan kepala desa pada akuntabilitas pengelolaan dana desa diperoleh nilai signifikasi sebesar 0,043 dengan nilai koefisien beta 0,077. Nilai Signifikansi 0,043 < 0,05 mengindikasikan bahwa $\mathrm{H}_{1}$ diterima. Hasil ini mempunyai arti bahwa kepemimpinan kepala desa berpengaruh positif dan signifikan pada akuntabilitas pengelolaan dana desa di Kecamatan Denpasar Utara. Hasil ini mendukung teori peran yang menjelaskan bahwa kepala desa dalam mengelola dana desa merupakan penanggung jawab berjalannya kegiatan yang sudah dituangkan kedalam bentuk anggaran (Silva, 2016). Teori peran juga sejalan dengan Permendagri No. 20 Tahun 2018 yang menjelaskan bahwa kepala desa merupakan penanggung jawab pengelola keuangan desa. Mekanisme pertanggungjawaban yang dilakukan oleh kepala desa adalah dengan menyampaikan laporan realisasi pelaksanaan APBDesa kepada bupati atau walikota melalui camat. Pelaporan yang dilakukan oleh kepala desa tersebut bertujuan untuk menciptakan simetri informasi antara agen dan juga prinsipal sehingga permasalahan keagenan dapat diminimalisir.

Hasil penelitian ini didukung "dengan hasil wawancara yang menjelaskan bahwa dalam proses pengelolaan dana desa sudah berjalan sesuai dengan regulasi dan mekanisme yang dimana dalam pengelolaan keuangan dana desa melalui proses perencanaan, penganggaran, pelaksanaan, penatausahaan, pelaporan dan pertanggungjawaban. Dalam mengevaluas kinerja kepala desa tiap desa yang ada 
di Kecamatan Denpasar Utara menerima kritik dan saran serta pendapat dari perangkat desa maupun masyarakat melalui survei yang dapat diakses melalui website kantor desa. Dewi \& Gayatri (2019) menjelaskan bahwa tercapainya tujuan dari organisasi sangat dipengaruhi oleh peran pemimpin didalam organisasi tersebut. Hasil penelitian ini sejalan dengan penelitian yang dilakukan oleh Ratu et al. (2018) yang menyimpulkan bahwa kepemimpinan berpengaruh positif signifikan terhadap kinerja penyusunan laporan akuntabilitas. Peran kepala desa dalam pengelolaan dana desa sangatlah penting guna mencapai tujuan yang sudah dijabarkan kedalam bentuk anggaran. Kepemimpinan yang baik dari kepala desa akan selalu mengupayakan agar tercapainya tujuan bersama dan menghindari tujuan yang hanya memberikan keuntungan bagi dirinya sendiri. Kemampuan kepala desa dalam merangkul masyarakat serta perangkat desa untuk bersama-sama mewujudkan tujuan dari dana desa akan sangat memengaruhi akuntabilitas dari pengelolaan dana desa.

Berdasarkan hasil analisis pengaruh kompetensi perangkat desa pada akuntabilitas pengelolaan dana desa diperoleh nilai signifikansi sebesar 0,020 dengan nilai koefisien beta 0,121. Nilai Signifikansi 0,020<0,05 mengindikasikan bahwa $\mathrm{H}_{2}$ diterima. Hasil ini mempunyai arti bahwa kompetensi perangkat desa berpengaruh positif dan signifikan pada akuntabilitas pengelolaan dana desa di Kecamatan Denpasar Utara. Hasil penelitian ini sejalan dengan teori agensi yang menjelaskan bahwa perangkat desa merupakan prinsipal yang diberikan kepercayaan untuk mengelola dana desa untuk meningkatkan kesejahteraan masyarakat (Panda \& Leepsa, 2017). Perangkat desa dalam mengelola dana desa harus taat terhadap aturan-aturan yang berlaku karena ketaatan perangkat desa merupakan cerminan atas kompetensi yang dimilikinya seperti yang dijelaskan oleh teori kepatuhan (Umar et al., 2018).. Kompetensi yang dimiliki oleh perangkat desa berperan dalam proses pelaksanaan hingga pertanggungjawaban kepada pemerintah pusat maupun kepada masyarakat atas dana yang diperoleh. Faktor yang menghambat pengelolaan dana desa adalah terbatasnya kemampuan aparatur desa dalam mengelola keuangan desa.

Hasil penelitian ini diperkuat dengan hasil wawancara yang menjelaskan bahwa perangkat desa sudah mengikuti pembinaan tentang dana desa serta mampu mengoperasikan komputer dalam melaksanakan tugasnya. Perangkat desa sudah dapat mempertanggungjawabkan pelaksanaan pengelolaan terkait dana desa melalui laporan pertanggungjawaban realisasi pelaksanaan APBDes tahun anggaran serta siskeudes. Seluruh pengelolaan keuangan dilakukan secara terbuka serta transparan dan dapat diakses di website tiap OPD kantor Desa terkait. Kompetensi merupakan kemampuan untuk dapat melakukan pekerjaan yang berlandaskan pada keterampilan dan pengetahuan yang dimiliki serta didukung oleh tuntutan kerja. Kompetensi perangkat desa sangatlah diperlukan dalam mengelola dana desa guna mencapai tujuan diberikannya dana desa melalui pengetahuan, keterampilan dan perilakunya dalam bekerja (Dewi \& Gayatri, 2019). Hasil penelitian ini sejalan dengan Dewi \& Gayatri (2019) yang menyimpulkan bahwa kompetensi secara parsial berpengaruh positif signifikan pada akuntabilitas. Kompetensi merupakan kemampuan yang diperoleh individu dari proses pembelajaran serta pengalamanan. Kompetensi yang dimiliki tersebut akan sangat berperan dalam melaksanakan tugasnya. Tingginya kompetensi yang 
dimiliki oleh perangkat desa akan sangat membantu proses pengelolaan dana desa dari proses penyusunan anggaran hingga nantinya anggaran tersebut dilaporkan. Semakin tinggi kompetensi yang dimiliki oleh perangkat desa, maka semakin tinggi pula akuntabilitas dari pengelolaan dana desa (Purdiyanto et al., 2020).

Berdasarkan "hasil analisis pengaruh partisipasi masyarakat pada akuntabilitas pengelolaan dana desa diperoleh nilai signifikansi sebesar 0,180 dengan nilai koefisien beta 0,437 Nilai signifikansi 0,180 >0,05 mengindikasikan bahwa $\mathrm{H}_{3}$ ditolak. Hasil ini mempunyai arti bahwa partisipasi masyarakat tidak berpengaruh signifikan pada akuntabilitas pengelolaan dana desa di Kecamatan Denpasar Utara. Hasil penelitian ini bertentangan dengan hasil yang diperoleh Mahayani (2017), Dewi \& Gayatri (2019) menyimpulkan partisipasi masyarakat berpengaruh positif signifikan pada akuntabilitas pengelolaan dana desa. Namun hasil penelitian ini sejalan dengan hasil yang diperoleh Retnaningtyas (2016) yang menyimpulkan partisipasi tidak berpengaruh signifikan pada akuntabilitas pengelolaan dana desa. Hasil penelitian ini diperkuat dengan hasil wawancara yang menjelaskan bahwa tingkat partisipasi masyarakat dalam pelaksanaan pengelolaan dana desa di Kecamatan Denpasar Utara selalu berpartisipasi dengan baik, masyarakat selalu dilibatkan dalam proses perencanaan dan pelaksanaannya, walaupun masih terdapat masyarakat yang kurang peduli dan paham akan pentingnya peran aktif masyarakat dalam pengelolaan dana desa (Yunita \& Christianingrum, 2018).

Penelitian ini memiliki beberapa implikasi, diantaranya hasil penelitian ini dapat memberikan tambahan informasi dalam kajian empiris khususnya mengenai kepemimpinan kepala desa, kompetensi perangkat desa serta partisipasi msyarakat pada akuntabilitas pengelolaan dana desa. Hasil dari penelitian ini mendukung teori agensi yang digunakan untuk memformulasikan konflik kepentingan yang terjadi antara agen dan juga prinsipal, untuk itu diperlukan adanya pertanggungjawaban berupa akuntabilitas untuk menciptakan simetri informasi antara agen dan juga prinsipal. Hasil ini juga sejalan dengan teori peran yang menjelaskan keterlibatan pemimpin serta partisipasi masyarakat sangat memengaruhi akuntabilitas pengelolaan dana desa. Implikasi penelitian ini bagi pelaku organisasi sektor publik adalah pentingnya memerhatikan kepemimpinan kepala desa, kompetensi perangkat desa serta partisipasi masyarakat guna mencapai akuntabilitas. Sehingga tujuan yang diharapkan dengan adanya pemberian dana desa dapat tercapai secara maksimal. Selain itu juga, dengan adanya Kepemimpinan, komptensi, serta partisipasi masyarakat permasalahan-permasalahan yang mungkin terjadi selama proses pengelolaan dana desa dapat diminimalisir.

\section{SIMPULAN}

Berdasarkan pembahasan yang sudah dijelaskan, dapat disimpulkan bahwa kepemimpinan kepala desa yang baik akan memastikan tujuan dari pemberian dana desa secara maksimal, jadi semakin baik kepemimpinan kepala desa maka semakin meningkatkan akuntabilitas pengelolaan dana desa, begitu juga dengan kompetensi dari perangkat desa. Tingginya kompetensi perangkat desa dalam pengelolaan dana desa yang bersumber dari pengalaman dan pengetahuan dari 
perangkat desa akan meningkatkan akuntabilitas pengelolaan dana desa. Pengelolaan dana desa juga perlu melibatkan masyarakat karena masyarakat merupakan prinsipal dan juga subjek dari pembangunan yang paling mengetahui permasalahan yang dihadapi daerahnya, namun masih terdapat masyarakat yang kurang paham akan pentingnya peran aktif dalam pelaksanaan pengelolaan dana desa.

Berdasarkan uraian pembahasan serta simpulan dari penelitian ini, saran yang dapat diberikan kepada pemerintah selaku pengelola dana desa yang telah diberikan kepercayaan harus lebih memerhatikan kepala desa selaku pemimpin harus mampu memimpin baik dalam mengambil keputusan maupun menciptakan suasana kerja yang harmonis dengan perangkat desa guna memaksimalkan kinerja, selain itu perlu diperhatikannya kompetensi dari perangkat desa yang nantinya berguna dalam proses pengelolaan seperti adanya kompetensi minimal bagijabatan kaur keuangan, kemampuan dalam penggunaan teknologi guna memaksimalkan kinerja perangkat desa. Masyarakat sebagai prinsipal dan juga subjek pembangunan desa harus mampu ikut berperan ak tif dalam pengelolaan dana desa dengan ikut mengawasi, mengontrol dan memberi saran sehingga dapat meminimalisir adanya penyalahgunaan kekuasaan dalam pengelolaan dana desa, serta tujuan dari pemberian dana desa dapat terwujud secara maksimal. Saran yang dapat penulis berikan kepada peneliti selanjutnya agar menambahkan variabel lain seperti budaya organisasi, pengendalian akuntabilitas dan komitmen dari suatu organisasi yang tidak dimasukkan ke model penelitian ini guna memperoleh bukti empiris terkait akuntabilitas pengelolaan dana desa.

\section{REFERENSI}

AbRahman, N. A., Omar, N., Rashid, N. M. N. N. M., \& Ramli, A. (2016). Improving Employees Accountability and Firm Performance through Management Accounting Practices. Procedia Economics and Finance, 35(16), 92-98. https:/ /doi.org/10.1016/s2212-5671(16)00013-7

Adnyaswari, N. A., \& Adnyani, I. G. A. D. (2017). Pengaruh Dukungan Sosial dan Burnout Terhadap Kinerja Perawat Rawat Inap RSUP Sanglah. E-Jurnal Manajemen, 6(5), 2474-2500.

Anto, R. P., \& Amir, M. (2017). Competence of Village Apparatus In Management of Village Funds in North Konawe Regency-Indonesia. IOSR Journal of Business and Management, 19(11), 66-71. https://doi.org/10.9790/487X1911076671

Arta, I. M. A. S., \& Rasmini, N. K. (2019). Pengaruh Kejelasan Sasaran Anggaran, Sistem Pelaporan dan Partisipasi Masyarakat Pada Akuntabilitas Pengelolaan Dana Desa. E-Jurnal Akuntansi, 26(1), 709. https:/ / doi.org/10.24843/eja.2019.v26.i01.p26

Atmadja, A. T., \& Saputra, K. A. K. (2018). Determinant factors influencing the accountability of village financial management. Academy of Strategic Management Journal, 17(1), 1-10.

Carreira, V., Machado, J. R., \& Vasconcelos, L. (2017). Citizen Involvement in the Decision-Making Processes of Environmental and Spatial Planning, and it's Influence on Public Participation: a Case Study of Lisbon. International 
Journal of Political Science, 3(1), 23-29. https://doi.org/10.20431/24549452.0301004

Curral, L., Marques-Quinteiro, P., Gomes, C., \& Lind, P. G. (2016). Leadership as an emergent feature in social organizations: Insights from a laboratory simulation experiment. PLoS ONE, 11(12), 1-16. https:/ / doi.org/10.1371/journal.pone.0166697

Dewi, N. K. A. J. P., \& Gayatri, G. (2019). Faktor-Faktor Yang Berpengaruh Pada Akuntabilitas Pengelolaan Dana Desa. E-Jurnal Akuntansi, 26(2), 1269. https:/ / doi.org/10.24843/eja.2019.v26.i02.p16

Han, Y., \& Perry, J. L. (2020). Employee accountability: development of a multidimensional scale. International Public Management Journal, 23(2), 1.

Mahayani, N. L. A. (2017). Prosocial Behavior Dan Persepsi Akuntabilitas Pengelolaan Dana Desa Dalam Konteks Budaya Tri Hita Karana. Jurnal $\begin{array}{lllll}\text { Ilmiah Akuntansi Dan Bisnis, } & 129 .\end{array}$ https:/ / doi.org/10.24843/jiab.2017.v12.i02.p07

Mantako, S. A. A., Said, D., \& Nurleni. (2019). The Influence of Organizational Commitment, Competence of Village Fund Management Offficers, and Utilization of Information Technology on Accountability of Village Financial Management. AFEBI Accounting Review (AAR), 1(20), 94-105.

Panda, B., \& Leepsa, N. M. (2017). Agency theory: Review of theory and evidence on problems and perspectives. Indian Journal of Corporate Governance, 10(1), 74-95. https:/ / doi.org/10.1177/0974686217701467

Pawirosumarto, S., Sarjana, P. K., \& Gunawan, R. (2017). The effect of work environment, leadership style, and organizational culture towards job satisfaction and its implication towards employee performance in Parador Hotels and Resorts, Indonesia. International Journal of Law and Management, 59(6), 1337-1358. https:// doi.org/https:// doi.org/10.1108/IJLMA-102016-0085

Pertiwi, A. D. (2017). Pengaruh Gaya Kepemimpinan, Partisipasi Anggaran, dan Pengendalian Internal Terhadap Kinerja Pemerintah Daerah Kabupaten Wajo. Jurnal Fakultas Ekonomi Dan Bisnis Universitas Hasanuddin, 1(1), 1.

Pramayoga, I. B., \& Ramantha, I. W. (2019). Pengaruh KejelasanSasaran Anggaran, Kompetensi Aparatur Desa, dan Kepemimpinan Pada Akuntabilitas Pengelolaan Dana Desa. E-Jurnal Akuntansi, 30(1), 226-237.

Prasetya, I. K. Y. B., Prayudi, M. A., \& Diatmika, I. P. G. (2017). Pengaruh Kompetensi Sumber Daya, Pemahaman, Dan Pengawasan Terhadap Kualitas Sistem Keuangan Desa Di Kabupaten Buleleng. JIMAT (Jurnal Ilmiah Mahasiswa Akuntansi S1), 8(2), 1-10. https:/ / doi.org/10.23887/jimat.v8i2.14758

Purdiyanto, H., Pituringsih, E., \& Inapty, B. A. (2020). Determinants of Village Financial Management Accountability. IOSR Journal of Businees an Management, 1(1),1357-1373. https://doi.org/10.2991/assehr.k.200407.032

Ratu, N. I. H., Sari, M. M. R., \& Putri, I. G. A. A. D. (2018). Kecerdasan Spiritual Memoderasi Gaya Kepemimpinan Dan Budaya Organisasi Pada Kinerja Penyusun Laporan Akuntabilitas Kinerja Instansi Pemerintah (Lakip). EJurnal Ekonomi Dan Bisnis Universitas Udayana, 9(1), 57. https:/ / doi.org/10.24843/eeb.2018.v07.i01.p03 
Retnaningtyas, T. W. (2016). Analisis Akuntabilitas Kinerja Keuangan Satuan Kerja Perangkat Daerah Kota Surakarta. Jurnal Akuntansi, 6(2), 65-86.

Silva, A. (2016). What is Leadership ? Video: What is leadership? Journal of Business Studies Quarterly, 8(1), 1-5.

Sugista, R. A. (2017). Pengaruh Transpansi, Akuntabilitas, dan Partisipasi Masyarakat Dalam Pengelolaan Keuangan Desa Terhadap Pembangunan Desa. Jurnal Sosiologi, 1(18), 1.

Umar, H., Usman, S., \& Purba, R. B. R. (2018). The influence of internal control and competence of human resources on village fund management and the implications on the quality of village financial reports. International Joumal of Civil Engineering and Technology, 9(7), 1526-1531.

Vesey, J. (2019). Workplace Accountability: Exploring the Role of Strong and Weak Accountability Environments on Employee Effort and Performance. The Journal of International Management Studies, 14(2), 23-30.

Yunita, A., \& Christianingrum. (2018). Measurement of Accountability Management of Village Funds. Integrated Journal of Business and Economics, 2(1), 99. https:// doi.org/10.33019/ijbe.v2i1.62

Yusof, N. Z. M. (2016). Context Matters: A Critique of Agency Theory in Corporate Governance Research in Emerging Countries. International Journal of Economics and Financial Issues, 6(s7), 154-158. 